\title{
Compliance in "exceptional" trade disputes: a set-theoretical approach
}

DOI: http://dx.doi.org/10.1590/0034-7329202000103

Rev. Bras. Polít. Int., 63(1): e003, 2020

Revista Brasileira de Política Internacional ISSN 1983-3121

http://www.scielo.br/rbpi

\section{Rodrigo Fagundes Cezar ${ }^{1}$}

${ }^{1}$ Institut de Hautes Études Internationales et du Développement, International Relations/Political Science, Geneve, Switzerland

(rodrigo.fagundes@graduateinstitute.ch)

ORCID ID:

orcid.org/0000-0002-9966-9972
Copyright:

- This is an open-access article distributed under the terms of a Creative Commons Attribution License, which permits unrestricted use, distribution, and reproduction in any medium, provided that the original author and source are credited.

- Este é um artigo publicado em acesso aberto e distribuído sob os termos da Licença de Atribuição Creative Commons, que permite uso irrestrito, distribuição e reprodução em qualquer meio, desde que o autor e a fonte originais sejam creditados.
Received: July 28, 2019 Accepted: November 18, 2019

\section{Introduction}

Oountries constantly accuse each other of implementing policies that are inconsistent with multilateral trade rules. When that happens, trade partners that feel economically impaired by those policies can ultimately access World Trade Organization's (WTO) Dispute Settlement Mechanism (DSM) and have WTO judges assess whether there was any breach of multilateral trade agreements. In some cases, however, countries can justify policies that are inconsistent with their multilateral trade obligations by resorting to Article XX (General Exceptions) of the General Agreement on Trade and Tariffs (GATT). For instance, during a WTO dispute against the European Communities (EC) (DS322), Brazil invoked Article XX to justify the prohibition of the importation of retreaded tires on the imperative of protecting human health and the environment. Those disputes can bear 
relevant impacts on environmental governance, as attested by the US-Shrimp (DS58) and US-Dolphin (DS381) cases. Defendants invoking GATT Article XX claim that the challenged policies are exceptional - in the sense of being justifiable under GATT's General Exceptions - and that therefore multilateral trade rules cannot prevent them from implementing such policies. In an effort to start making sense of compliance response in "exceptional" trade disputes, this article analyzes the combinations of conditions that explain the length of WTO controversies that invoke GATT's Article $\mathrm{XX}^{1}$.

The first point of departure of this work is the need to go beyond single case studies when analyzing disputes in which one of the parties invoke GATT Article XX provisions. Single case studies (e.g., Varella 2014; Cezar 2019) do not really capture the dynamics of "exceptional" disputes as a whole. This article, although encouraging further in-depth case studies, is also the first to study "exceptional" disputes as a target category. The second point of departure of this work is the evidence that despite the existence of a mechanism of "reverse consensus" aimed at reducing the length of controversial disputes at the WTO, the length of disputes evoking GATT Art. XX varies considerably. That variation is counterintuitive if one considers that governments may prefer to show strategic restraint and avoid triggering long disputes when potentially controversial issues are at hand. For instance, while the EC-Asbestos (DS135) case lasted only 200 days, the US-Shrimp case lasted 1287 days. It is the aim of this article to explain such variation in dispute length. Length here is measured as the number of days from the date of circulation of the Panel's Report to the date in which the respondent notified the implementation of the report or entered into an agreement that de facto ended the dispute.

Previous works suggest that (1) the lobbying of domestic interests, (2) institutional variables and (3) retaliatory power are of particular importance to understand the length of disputes when holding other variables constant (Brimeyer 2001; Sattler and Bernauer 2011; Mavroidis 2012; Spilker 2012; Poletti and De Bièvre 2014; Peritz 2016). Recent research also indicates that civil society organizations $\left(\mathrm{CSOs}^{2}\right)$ played an important role in the length and outcome of certain disputes involving GATT Art. XX exceptions (Cezar 2018; 2019). Many CSOs are highly concerned that the GATT/WTO system will constrain national policy space and reduce the policy autonomy of national governments. When countries claim that their policies are "exceptional" and that therefore the government should be entitled to proceed

\footnotetext{
${ }^{1}$ In full, GATT Art. XX applies to measures (a) necessary to protect public morals; b) necessary to protect human, animal or plant life or health; c) relating to the importations or exportations of gold or silver; d) necessary to secure compliance with laws or regulations which are not inconsistent with the provisions of GATT; e) relating to the products of prison labor; f) imposed for the protection of national treasures of artistic, historic or archaeological value; g) relating to the conservation of exhaustible natural resources; h) undertaken in pursuance of obligations under any intergovernmental community agreement which conforms to certain criteria; i) export restriction for government stabilization purposes, $\mathrm{j}$ ) the acquisition or distribution of products generally, or to offset local shortage. A necessary condition for GATT-inconsistent measures to be defensible under Article XX is that it should not be applied as a means of arbitrary or unjustifiable discrimination where the same conditions prevail. Because of that two-tiered condition, it is usually very difficult for GATT Art. XX cases to make the cut.

${ }^{2} \mathrm{CSO}$ are here defined as non-market and non-state organizations that organize to purse public interests (Working with civil society in foreign aid: possibilities for south-south cooperation? 2013).
} 
with those policies even if they are GATT-inconsistent, CSO concerns are strongly activated. Therefore, even if CSOs usually have difficulty to mobilize, it is possible to affirm that in "exceptional" disputes they will more readily engage in political activity. Given the expected relevance of the topic for CSOs and assuming that import-competing and export-competing industries can easily overcome their collective action dilemmas, I expect variation in the mobilization of CSOs to help me understand variation in the length of "exceptional" disputes. This paper puts that logic to test.

To date, few works have given due attention to the combinations of factors that may affect compliance response in trade controversies, except for Yildirim (2018) and Young (2019), whose works are nevertheless focused only on trade disputes having the EU as a respondent. Instead, the existing literature is usually focused on the mean effect of a certain variable while controlling for others. However, given the causal complexity of political events, such a strategy may not fully capture the nuances of the politics of WTO compliance. The Qualitative Comparative Analysis Method (QCA) may therefore offer a fruitful alternative to understand the complexity of factors influencing the length of WTO disputes. By focusing on set-relations, QCA's set-theoretic rationale allows (1) the analysis of multiple equifinal paths leading to the same outcome; and (2) it indicates the conditions that may be necessary or sufficient to the outcome.

In line with this papers' objective and based on WTO (WTO dispute settlements: one-page case summaries 2017, 229-230), I select all 19 cases in which one of the parties invoked GATT Art. XX (only concluded cases that reached at least the panel phase ${ }^{3}$ ). The empirical strategy I use relies on a fuzzy-set qualitative comparative analysis (QCA), which I ran using $\mathrm{R}$. The conditions selected to integrate the analysis are in line with the literature: (1) the lobbying of domestic interests (here I focus on CSOs), (2) institutional variables and (3) retaliatory power. To offer a more complete picture, beyond interests, institutions and power, I also add (4) rules, in line with works that underscore the importance of the number of agreements referred to in the request for consultations in influencing compliance response (Spilker 2012). My findings indicate that theoretically relevant conditions brought to fore by the literature on WTO compliance in general also hold for "exceptional" cases. The role of CSO mobilization, veto players and retaliatory power is to be highlighted. However, domestic and international conditions only matter in conjunction and not separately. In addition, none of the conditions studied are necessary or sufficient on their own. That underscores the causal complexity of "exceptional" WTO disputes and their empirical heterogeneity.

Bearing all the above in mind, in the pages that follow I present 1) the analytical framework of this research; 2) the data, outcomes and conditions guiding the analysis; 3) the analysis of necessity and sufficiency and the robustness tests; 4) an interpretation of the results; 5) a succinct plausibility probe on the Brazil-EC controversy over the importation of retreaded tires; and 6) a

\footnotetext{
${ }^{3}$ Many disputes are solved before escalating, during the consultations phase. In this work, I am only looking at disputes that reach at least the panel phase with a view to evaluating how long it took until the country complied with the panel decisions.
} 
conclusion. This article is the first of its kind making sense of the political determinants of disputes that claim to be GATT-inconsistent for legitimate and justifiable reasons. By doing so using QCA, it contributes to methodological plurality in the study of WTO compliance. By focusing on CSO mobilization, this paper also allows me to further test the influence of NGOs, think tanks and other not-for-profit organizations on WTO compliance. In bringing all those contributions to the same place, this paper explores new avenues for studying the politics of WTO compliance using the QCA method.

\section{Analytical framework}

\section{Domestic level: issue salience and veto players}

Based on Olson (1997) one would expect business groups to be able to mobilize more easily than CSOs, all other things constant (see also Dür and De Bièvre 2007). However, as I mentioned above, this is different in the case of "exceptional" disputes since the mobilization baseline of civil society organizations is considerably changed. In "exceptional" disputes, CSOs are able to ratchet up their lobbying efforts and offer incentives for office-seeking policymakers to hear their demands. CSOs lobbying efforts may take the form of "noise" strategies (i.e., public demonstrations), potentially with recourse to transnational advocacy networks (Keck and Sikkink 1998). To unveil variation in CSO mobilization, I use issue salience as a proxy for the level of CSO political mobilization, inspired by previous works on issue and public salience (e.g., Dür and Mateo 2014; Rasmussen et al. 2014). My argument is based on the premise that business interests can mobilize easily and that policymakers are driven by the objective of staying in office.

Salience here is broadly defined as the importance that actors attribute to a certain political matter (Beyers et al. 2015). Before going into details of why and how salience matters to political mobilization, it is important to first differentiate between public and issue salience in the context of this research. The issue analyzed in this paper is the connection between trade and the exceptions allowed under GATT Article XX. As pointed out by Beyers et al. (2015), something is only salient for someone, meaning that it is important to have an actor-centered conceptualization of salience. As such, I focus on salience for civil society organizations. Given that an issue may be salient for CSOs and not for the general public, I am not necessarily interested in whether an issue is publicly salient, as long as it is so for the CSOs involved. The rationale behind the connection between salience and mobilization is that when an issue is very salient for certain CSOs, any loss - i.e., granting a victory to actors with an opposing preference - generates concentrated rather than diffuse costs. Therefore, the anticipation of such losses triggers a more consistent mobilization among the CSOs involved. 
The association between issue salience and political mobilization in this paper has advantages $v i s$ - $\grave{a}$-vis other works that use the number of NGOs in a country as a proxy for political activism (Binder and Neumayer 2005; Bohlmet et al. 2015). As Bohlmet et al. (2015) admit, a large number of NGOs may actually dilute their political activism since it can exacerbate their coordination problems. In turn, when an issue is considered salient by many NGOs, think tanks and advocacy groups, this indicates that the topic triggers serious ethical/health/safety/ environmental concerns, and can motivate CSO action. Beyond that, it may also indicate that the issue area of the dispute is responsible for a considerable share of the donations/resources received by the organization at hand (see Johnson and Prakash 2007). The US-Dolphin controversy offers an example: some of the most active NGOs involved in the dispute were the ones that had full departments devoted to the protection of marine mammals. Therefore, finding a greater number of CSOs which consider a specific dispute salient does not raise concerns of coordination problems just as much as simply counting the number of NGOs in a certain country; on the contrary, it reinforces how concentrated potential losses would be for organizations operating in the disputed sector.

With the above in mind, I would expect a high degree of issue salience $(S)$ to be part of configurations that lead to lengthier compliance $(C)$. As such, it would be counterintuitive to find $S$ as part of a combination leading to swifter compliance $(-C)$. According to Poletti and De Bièvre (2014), mobilization only leads to a longer compliance period when in combination with a certain number of veto players. The logic behind veto players is that the greater the distribution of decision power among domestic actors, the more difficult it is to introduce policy change (Tsebelis 2012). Such logic has been tested across different political systems (e.g., Tsebelis 1995). Given that compliance may involve some degree of policy change, it is plausible to connect veto players to other conditions affecting the timing of compliance. Despite its importance, the number of veto players in a country is likely not a necessary condition to longer disputes. Indeed, the literature considers that institutional constraints may be surpassed by strong preferences (Milner 1997). In result, it would not be counterintuitive to find combinations of $V$ that are sufficient to $\sim C$. I also expect to find combinations of $S+V$ (salience or veto players) to be sufficient but not necessary to $C$. Based on Polleti and De Bièvre (2014), I expect to find combinations of $S^{*} V$ (salience and veto players) leading to $C, S$ being, as I mentioned, a proxy for CSO mobilization. Finally, based on the findings of the recent scholarship linking domestic politics and compliance responses, I also expect a path including interests and institutions to explain a large number of disputes.

\section{International level: retaliatory power and number of potentially breached agreements}

Domestic institutions and interests are not the only conditions influencing the timing of compliance. WTO's dispute settlement mechanism (DSM) is sensitive to bargaining asymmetries. Given that multilateral trade agreements are self-enforcing, compliance response in WTO 
controversies is dependent upon power asymmetries. Mavroidis (2012) argues that powerful nations may have an "incentive to cheat" in the WTO system, because "WTO DSM does not contain a framework to 'punish' an erring member - the objective is to merely induce compliance" (Mavroidis 2012, 2). As such, power disparities may lead to lengthier disputes when the exports of the respondent are not dependent on the complainant. An erring party can make the dispute drag on for years before retaliation is authorized and, even then, such outcome can have negative impacts on the welfare of the consumers in the complainant country. As such, a plausible hypothesis is that the greater the retaliatory power of the respondent vis-à-vis the complainant, the longer a dispute, given that the respondent has no real incentive to comply and the complainant has limited means available for retaliation. Spilker (2012), Sattler et al. (2014) and others confirm that expectation using relative export dependence as an indicator.

If on the one hand bargaining asymmetry in favor of the respondent can lead to lengthier compliance, the opposite (bargaining asymmetry favoring the complainant) may lead to a swifter process. As pointed out by Yildirim $(2018,8)$ "being at the mercy of the complainant's export market would create an additional push toward reaching a solution in order to avoid potential losses." Unlike Yildirim (2018), however, I do not consider retaliatory power to be bound by sector. The author's results focusing on sectoral export dependence are at odds with some of the existing literature and, as the author himself admits, the counterintuitive results "may be due to the substitutability of the complainant's market" (Yildirim 2018, 7). As such, I do not only focus on sector but rather on the total export output. With that in mind, I expect combinations including greater bargaining asymmetry favoring the respondent $(D)$ to be sufficient to lengthy compliance $(C)$; in turn, I expect combinations including $\sim D$ to be sufficient to $\sim C$. However, I expect neither to be individually necessary to the outcome.

The DSM is a rule-based system, despite being influenced by power asymmetries, as pointed out above. As such, and in addition to bargaining asymmetry among disputants, one would expect that the number of potentially breached rules matter to compliance timing. Some authors such as Spilker (2012) and Bohmelt and Spilker (2013) have indeed found the number of agreements cited in the request for consultations to be statistically significant in the analysis of lengthier compliance. The rationale is that the greater the extent of the possible breach (number of agreements mentioned in the request for consultations), the longer the process to bring the controversial policy measure into compliance. Despite the importance of legal and technical expertise in the WTO, I expect the number of agreements mentioned in the request for consultations $(N)$ to be neither individually necessary nor individually sufficient to a lengthier compliance. However, I expect it to be part of combinations that are sufficient to the outcome. This derives from my expectation that, although important, the number of agreements cited in the request for consultations can only matter in conjunction with other factors. Given the importance of power and rules, I do not expect a combination of veto players or issue salience $(V+S)$ or their negation $(-V+\sim S)$ to be necessary to a lengthy or swift compliance unless in conjunction with $D$ or $N$. 


\section{Methods}

This work uses the QCA method to achieve its objectives. Because QCA is a method still unknown to many, I added to the appendix ${ }^{4}$ of this article a short note on QCA's analytical steps. The main outcome (dependent variable) of this paper is lengthy compliance $(C)$, here defined as WTO disputes that take more than 850 days to reach an end. Given that there is no convention on how many days qualify a given dispute as short or long, the 850 days threshold is defined based on my knowledge of the cases. When accounting for issue salience, I count the number of CSOs submitting amici curiae ${ }^{5}$ to the WTO and complement that with the number of public statements issued by CSOs on the dispute and with a review of the literature. Regarding veto players, I use the PolConIII ${ }^{6}$ dataset to compose the fuzzy set. The number of agreements referred to in the request for consultations $(N)$ is a simple count of the agreements referred to by the complainant in the request for consultations. Finally, relative export dependence $(D)$ is measured using the GDP ratio between the complainant and the respondent, with $\sim D$ meaning high export dependence of the respondent vis-à-vis the complainant, and $D$ meaning high export dependence of the complainant $v i s$ - $a$-vis the respondent. Further detail on how the conditions were defined and measured can be found in the appendix.

Table 1. Fuzzy-set membership values

\begin{tabular}{lccccc}
\hline \multicolumn{1}{c}{ Dispute } & C & S & D & V & N \\
\hline ArgHidesLeather & 0.32 & 0 & 0 & 1 & 0 \\
BrazilTires & 0.96 & 1 & 0.2 & 0.77 & 0 \\
CanadaPeriodicals & 0.68 & 0.01 & 0 & 0.87 & 0 \\
CanadaWheat & 0.53 & 0 & 0 & 0.87 & 0.33 \\
ChinaAudiovisual & 0.99 & 0 & 0.2 & 0.17 & 0.66 \\
ChinaAutoParts & 0.26 & 0 & 0.2 & 0.17 & 0.33 \\
ChinaRareEarths & 0.28 & 0.66 & 0.4 & 0.17 & 0.33 \\
ChinaRawMaterials & 0.65 & 0.66 & 0.2 & 0.17 & 0.66 \\
DRCigarettes & 0.05 & 0 & 0.6 & 0.08 & 0 \\
ECAsbestos & 0.03 & 1 & 0.8 & 0.8 & 0.66 \\
ECGeogIndications & 0.24 & 0 & 0.6 & 0.8 & 1 \\
ECSealProducts & 0.83 & 1 & 1 & 0.8 & 0.66 \\
ECTariffPreferences & 0.7 & 0 & 0.8 & 0.8 & 0 \\
KoreaBeef & 0.29 & 0.01 & 0 & 0.6 & 0.66 \\
\hline
\end{tabular}

\footnotetext{
${ }^{4}$ Cezar R. F. Appendix: Compliance in "Exceptional" Trade Disputes: A Set-Theoretical Approach. doi: https://doi.org/10.13140/ RG.2.2.28641.45925/1

${ }^{5}$ Amicus curiae is "[a] person who is not a party to a lawsuit but who petitions the court or is requested by the court to file a brief in the action because that person has a strong interest in the subject matter" (Garner 1999, 83, italics added).

${ }^{6}$ https://mgmt.wharton.upenn.edu/faculty/heniszpolcon/polcondataset/
} 
Table 1. continuation

\begin{tabular}{lccccc}
\hline MexicoSoftDrinks & 0.43 & 0 & 0 & 0.99 & 0 \\
USCOOL & 1 & 0.68 & 1 & 0.76 & 1 \\
USCustomBond & 0.27 & 0 & 0.8 & 0.76 & 1 \\
USGambling & 1 & 0.03 & 0.8 & 0.76 & 0 \\
USGasoline & 0.71 & 1 & 1 & 0.76 & 0.33 \\
USShrimp & 1 & 1 & 1 & 0.76 & 0 \\
\hline
\end{tabular}

\section{Analysis of necessity and sufficiency}

\section{Conditions leading to lengthy disputes (C)}

In the analysis of necessity, the parameters of fit below (Table 2) show that no condition reaches a consistency equal or greater than 0.9 (minimum for necessity to be established). Therefore, no condition is individually necessary to the outcome. A large number of veto players reaches a consistency of 0.637 , which nonetheless means that the set relations for that condition are weak. That naturally means that neither veto players nor issue salience are individually necessary for a dispute invoking GATT Art. XX exceptions to last longer. As a matter of fact, the only combination of conditions that reach a consistency of necessity of 0.9 - with a minimum possible coverage of necessity of at least 0.6 , and minimum possible relevance of necessity of at least $0.5-$ is $V+N$ (consistency of 0.908$)$.

Table 2. Consistency of necessity and of sufficiency for individual conditions of the outcome lengthy compliance (C)

\begin{tabular}{lcc}
\hline & $\begin{array}{c}\text { Consistency of necessity } \\
\text { (pof) }\end{array}$ & $\begin{array}{c}\text { Consistency of sufficiency } \\
\text { (QCAfit) }\end{array}$ \\
\hline Issue salience & 0.463 & 0.736 \\
Number of breached agreements & 0.446 & 0.656 \\
Relative export dependence & 0.598 & 0.699 \\
Veto players & 0.783 & 0.683 \\
Issue salience (negation) & 0.594 & 0.515 \\
Number of breached agreements (negation) & 0.733 & 0.664 \\
Export dependence (negation) & 0.531 & 0.573 \\
Veto players (negation) & 0.418 & 0.657 \\
\hline
\end{tabular}


In the analysis of sufficiency, the first step I take is to check whether any of the conditions and their negations is individually sufficient to the outcome using QCA fit, as indicated by Thomman et al. (2018). Issue salience $(S)$ is the only condition that goes above 0.7 , reaching a consistency of 0.736 . That being said, a consistency value of 0.736 is considered low according to the 0.8 threshold used in this paper as a minimum possible value for sufficiency to be established. $D$ is not per se sufficient to $C$, as well as $\sim D$ is not per se sufficient to $\sim C$. When setting the truth table, I define a consistency threshold of 0.8 for the analysis of lengthy compliance, which is in line with other QCA works (Epple et al. 2014; Schneider and Maerz 2017). The threshold is defined by examining the truth table and looking for large gaps, inconsistency and PRI (proportional reduction in inconsistency) between rows. With the intention of identifying potentially contradictory cases, I built one single truth table for both $C$ and $\sim C$ (Table 3 ). After creating the truth table of the conditions and outcomes, I use logical minimization to delete logical redundancies, based on the theoretical expectation that, individually, $S, D, N$ and $V$ will contribute to lengthier compliance, the intermediate solutions for $C$ is $S 1$. The parsimonious solution is the same as the intermediate one:

$$
(S 1)-V^{*} N+S^{*} V^{*}-N+D^{*} V^{*}-N \rightarrow C
$$

The minimized solution for $C$ displays coverage of 0.627 . This coverage is low if compared to works such as Schneider and Maerz (2017), which reach coverage of 0.80 or greater. I interpret such coverage to be minimally satisfactory for the model not to be considered trivial given the complexity of the topic. An alternative model with a lower, but still acceptable, level of consistency achieves greater coverage, as presented below. Still, the results point to the need for future works to include further variables in the analysis. The lengthy disputes explained by the minimized solution are China-Audiovisual (DS363), China-Raw Materials (DS394), Brazil-Tires (DS332), US-Gasoline (DS2), US-Shrimp (DS58), EC-Tariff Preferences (DS246) and US-Gambling (DS285). The consistency of necessity of the minimized solution is 0.912 , which points to a very high quality of the set relations. Separately, the equifinal paths to the solution do not reach high values on coverage. The combination with greatest raw coverage is $D^{*} V^{*}-N(0.373)$. In other words, individual paths or recipes are not per se empirically relevant. In the cases of US-Shrimp (DS58) and US-Gasoline (DS2), $S^{*} V^{*}-N$ and $D^{*} V^{*}-N$ are substitutable, meaning that it is not possible to know for sure whether $S$ or $V$ mattered in those cases. 


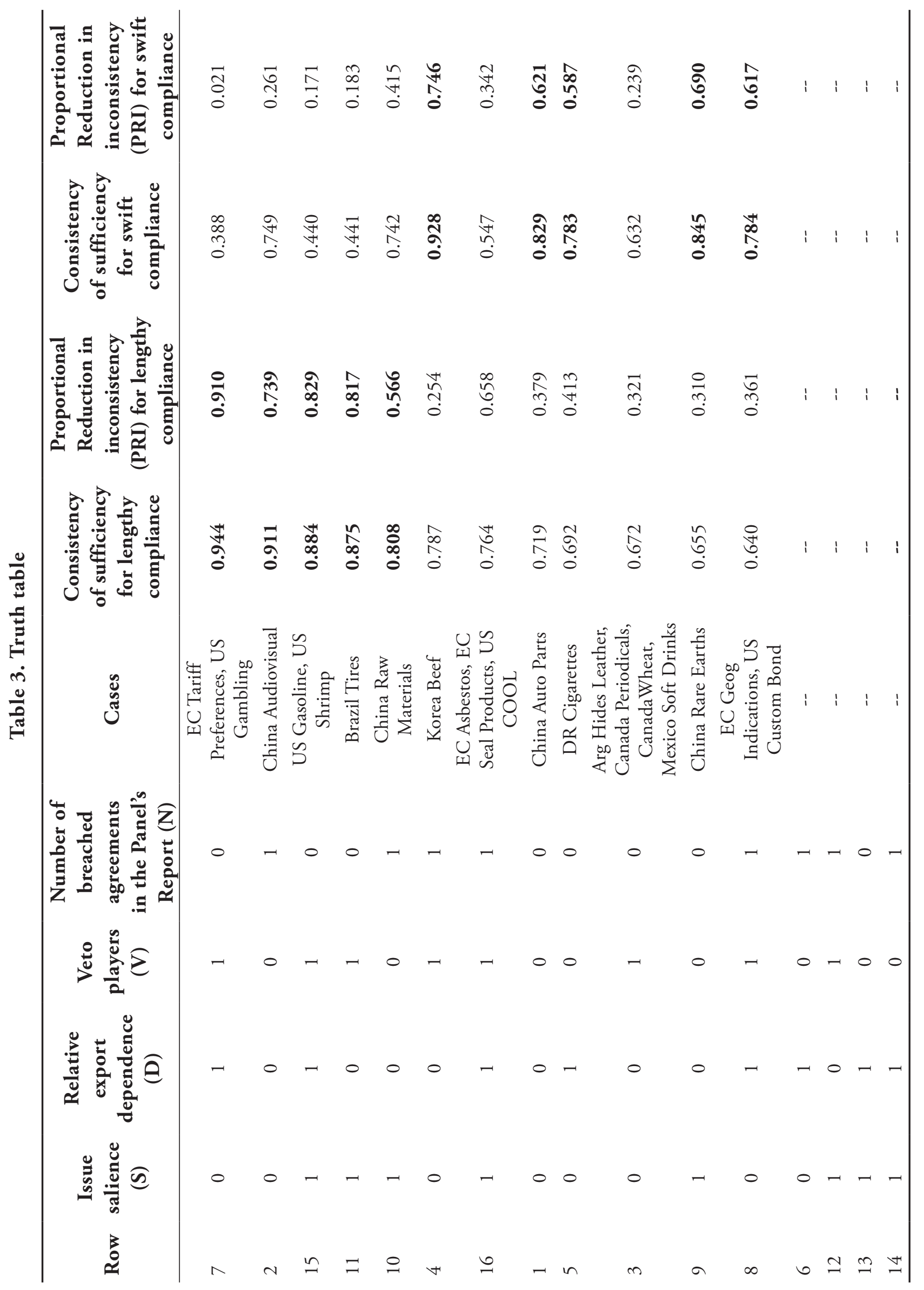


Advancing in the presentation and analysis of the results, it is possible to notice that high salience $(S)$ is associated with lengthier compliance, with no instances of $C$ associated with combinations including $-S$. Issue salience $(S)$, as a proxy for mobilization, shows up in combination with a large number of veto players $(V)$ in the Brazil-Tires (DS332), US-Gasoline (DS2) and US-Shrimp (DS58) cases. That being said, these two conditions only appear in conjunction with $-N$.

\section{Conditions leading to swift disputes $(\sim \mathrm{C})$}

As in the case of the conditions leading to lengthy disputes, in the case of swift compliance, I begin the analysis by observing whether each individual condition is necessary to the outcome $\sim C$. Once more, no condition reaches a consistency of 0.9 or greater, indicating that no condition is individually necessary to the outcome. Low issue salience reaches a consistency of 0.788 , which nonetheless means that the set relations for that condition are weak. Regarding the analysis of super subsets, of all the combinations of conditions that are considered necessary to $\sim C$, no result reaches at the same time a consistency of 0.9 , coverage of 0.6 and relevance of 0.5 .

Table 4. Consistency of necessity and of sufficiency for individual conditions of the outcome swift compliance $(\sim \mathrm{C})$

\begin{tabular}{lcc}
\hline & $\begin{array}{c}\text { Consistency of necessity } \\
\text { (pof) }\end{array}$ & $\begin{array}{c}\text { Consistency of } \\
\text { sufficiency (QCAfit) }\end{array}$ \\
\hline Issue salience & 0.285 & 0.355 \\
Number of breached agreements & 0.526 & 0.606 \\
Relative export dependence & 0.494 & 0.452 \\
Veto players & 0.721 & 0.492 \\
Issue salience (negation) & 0.788 & 0.534 \\
Number of breached agreements (negation) & 0.702 & 0.498 \\
Export dependence (negation) & 0.671 & 0.566 \\
Veto players (negation) & 0.535 & 0.658 \\
\hline
\end{tabular}

I now turn my attention to the conditions that may be individually sufficient to the outcome. No condition goes above the lowest possible consistency value of 0.7 , with $-V$ being the closest to it, with a score of 0.658 . For the analysis of sufficiency of $\sim C$, I set the consistency of necessity threshold at 0.78 . Despite 0.8 being the consistency threshold adopted by many QCA works, Wagemann and Schneider $(2007,29)$ indicate that "QCA researchers should resist as much as possible to follow conventions simply for the sake of being conventions and should, instead, 
explicitly argue for their decisions made on the level of consistency." I therefore choose the 0.78 threshold after observing the PRI gap between the rows in the truth table. When minimizing the truth table to exclude logical redundancies, I once more use the intermediate solution, indicating as theoretical expectations that $\sim V, \sim N, \sim D$ and $\sim S$ contribute to the outcome $\sim C$. With that in mind, the intermediate solution is $S 2$, below, and reaches coverage of 0.631 . The parsimonious solution is $\sim V^{*} \sim N+\sim S^{*} V^{*} N \rightarrow \sim C$ and reaches coverage of 0.686 .

$$
\text { (S2) } \sim S^{*} V^{*} N+\sim S^{*}-V^{*}-N+\sim V^{*}-D^{*}-N \rightarrow \sim C
$$

This coverage is minimally satisfactory, indicating that the results associated with the model are not trivial, although no single equifinal path to the solution reaches high coverage. In turn, the consistency of the final minimized solution is 0.828 , which points to the good quality of the set relations. The intermediate solution above explains six instances of swift compliance: Korea-Beef (DS161), EC-Geographic Indications (DS174), China-Autoparts (DS342), DR-Cigarettes (DS302), China-Rare Earths (DS431) and US-Customs Bond (DS345). The results show that the absence of high issue salience $(-S)$, either in conjunction with a large number of veto players $(V)$ and a great number of agreements referred to in the request for consultations $(N)$ or their absence $(-V ;-N)$, is associated with swift compliance. In addition, a high degree of bargaining asymmetry in favor of the complainant is part of a combination that is sufficient to swifter compliance. Once more, a low number of agreements mentioned in the request for consultations $(N)$ only contributes to swift compliance under very specific conditions, namely when there is a low number of veto players $(-V)$.

\section{Robustness tests}

I ran robustness tests with different model specifications and different calibrations to improve the confidence in the findings above. The robustness tests reinforce the importance of domestic and international factors if not as a "blend" of elements influencing compliance response, at least as equifinal combinations leading to it. That indicates that there may be certain cases in which domestic or international variables contribute to the outcome independently, therefore going against my expectations. Overall, the robustness tests indicate that the empirical results are acceptable in terms of their quality but they should nevertheless be approached with caution given caveats stemming from the calibration thresholds employed. A similar cautionary note applies to all QCA works that fail to present robustness tests with alternative model settings. I report the truth table for the alternative model (with lower quality of set relations) in the Table 5 above. Details on each of those tests and their results can be found in the appendix. 


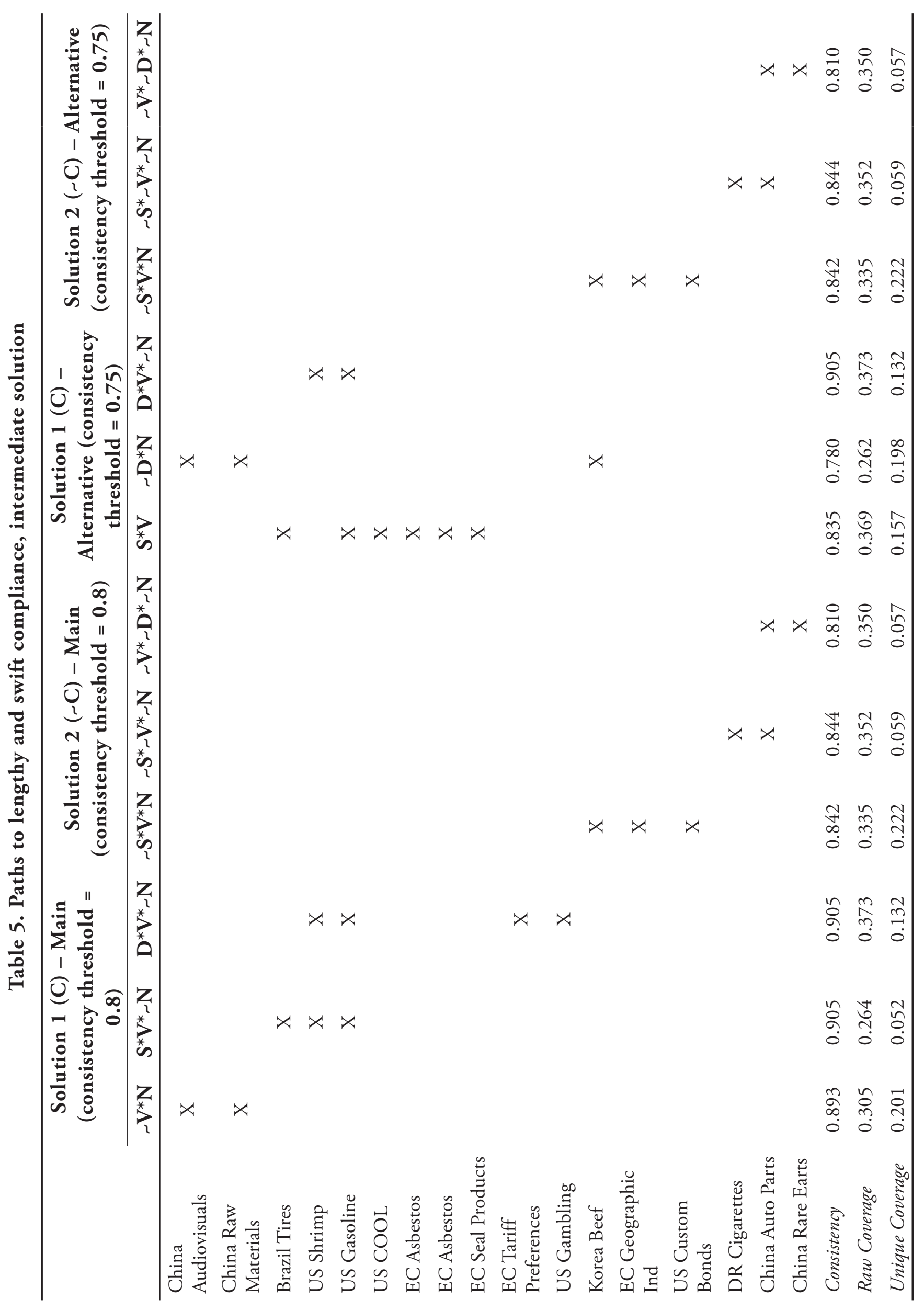




\section{Interpreting the results}

A few main results can be drawn from the analysis in the previous sections. Against my initial expectation that institutions and interests together would have a high coverage of sufficiency, they do not suffice to explain dispute length in a large number of "exceptional" disputes. Second, civil society mobilization, retaliatory power and veto players overall behave as theorized, each of them contributing to lengthier disputes. Third, no specific condition is per se necessary or sufficient to the analysis. All the above indicates that the mobilization of CSOs, veto players and retaliatory power matter in explaining the length of "exceptional" disputes, but only in association with other factors. The fact that $S^{*} V$ appears in many of the cases leading to $C$ attests that Poletti and De Bièvre's (2014) affirmation that mobilization leads to lengthier compliance when in combination with veto players hold true for "exceptional" disputes. This is illustrated by the Brazil-EC controversy, briefly presented below. It is largely known that retaliatory power matters in WTO disputes, therefore this paper extrapolates the importance of bargaining asymmetries (when in combination with other factors) to "exceptional" disputes ( $D$ was part of combinations leading to $C$ in the EC-Tariff Preferences, US-Gambling, US-Gasoline and US-Shrimp disputes). It is interesting to observe that export dependence and CSO mobilization only appear in association with veto players, thus suggesting that power is inextricably connected to domestic institutional conditions.

The findings also underscore that not always will civil society organizations be in disadvantage in their mobilization efforts vis-à-vis business groups. This reinforces preexisting findings about the relevant role of non-business interests in policymaking (e.g., Dür et al. 2015). In other words, civil society mobilization can be important to understand compliance response in highly salient cases. Because combinations of $D$ leading to $C$ never include $S$, domestic civil society mobilization seems to counteract the role of bargaining asymmetries, underscoring therefore the importance of the "paradox of weakness" (Schelling 1980). Whenever domestic interests are mobilized, negotiators gain more credibility in their claims in international negotiations. An interesting result is that both the combination including $\sim S^{*} V$ and the one including $\sim S^{*}-V$ contribute to swift compliance. This indicates, in line with my theoretical framework, that a large number of veto players is not always associated only with lengthy disputes. Mobilization is, in this case, a better predictor of the length of compliance responses (Poletti and De Bièvre 2014). The case of EC-Asbestos (DS135) in the alternative model deserves some attention. It is one case in which $S$ led to $\sim C$. That is because the EC-Asbestos case violates the assumption of business mobilization. In virtue of all kinds of bans on asbestos, business groups may have preferred not to mobilize to defend a dying industry. In that case, strong CSO mobilization led to a swifter, not longer, dispute, as the balance of domestic interests was too tilted in favor of one of the sides of the dispute (see, for instance, Cezar 2019).

It is also interesting to observe that both in the US-Shrimp (DS58) and in the US-Gasoline (DS2) controversies, $-\mathrm{N}$ was part of a combination leading to $\mathrm{C}$, contrary to my expectations 
and showing that the role played by WTO rules in exceptional disputes may have the opposite effect as theorized. In turn, in other three cases, $\mathrm{N}$ led to $\sim \mathrm{C}$. It may be that a large number of potentially breached agreements trigger a rapid response by creating the perception that a victory is difficult to achieve. In response, the policymaker may choose to exercise strategic restraint in order to save resources and avoid a long fight potentially imposing concentrated costs on some of its constituents. That happens only when the mobilization of civil society organizations is low. It is indeed quite suggestive that $\mathrm{N}$ leads to $\sim \mathrm{C}$ only when $\sim \mathrm{S}$. If civil society groups mobilize, it is unfeasible for the policymaker to exercise strategic restraint. Future research should further investigate this counterintuitive finding.

On a final note, the relatively low coverage of the solutions also indicates that there are conditions not explored in this paper that may play an important role in explaining the dispute length of "exceptional" controversies. In turn, low unique coverage means that we cannot specify which paths apply to which case as there is usually more than one path for the same set of cases. In some disputes, such as the Argentina-Hides and Leather (DS155), Canada-Periodicals (DS31), Canada-Wheat (DS276), Mexico-Soft Drinks (DS308), the conditions of sufficiency in the main model were not met. That is once more linked to the relatively low coverage of the model and points to the existence of other conditions that may help further explain the findings. Despite all that, as I indicated above, coverage is minimally satisfactory given the complexity of the object under scrutiny and the difficulty in measuring some of the main conditions analyzed, such as CSO mobilization. In addition, noting that empirical coverage does not mean theoretical relevance (Ragin 2006), the fact that $S, D$ and $V$ behave as expected lends more confidence to certain key theoretical expectations of my analytical framework.

\section{An illustrative case: the Brazil-EC controversy}

In the truth table (Table 5), Brazil's dispute against the EC on retreaded tires appears as a typical case in which issue salience and the number of domestic veto players played an important role. That outcome repeated itself in an alternative model configuration (with a lower consistency level). In both cases, $S^{*} V$ appeared as the only solution applying to the case. What follows is a short plausibility probe illustrating the suitability of that result, in an effort to lend more confidence to the QCA findings in contexts other than the US and Europe. In portraying the subject of the dispute, I start by indicating that certain industries import used tires that would otherwise be discarded, retread those tires and then sell them in the national market. The importing and reselling of retreaded tires is also common in certain countries. Especially after 1992, the Brazilian government started recognizing the importation of used tires as an environmental and public health issue. Having that in mind, the Federal government and the State of Rio Grande do Sul issued a series of regulations that in one way or another imposed barriers on the importation of 
used and retreaded tires ${ }^{7}$. In June 2005, the EC requested consultations with Brazil at the WTO, claiming that those measures discriminated against exports of EC's retreated tires to the Brazilian market. Consultations escalated to a formal dispute that lasted over four years.

Aimed at pushing for legislation limiting the import of retreaded tires and at avoiding the weakening of national regulations, CSOs participated actively during the WTO discussions by issuing reports and statements, and by submitting amici curiae to WTO. CSO actions included "outside lobbying" such as a protest in front of the Brazilian Congress on 4 September 2006 with the slogan "we do not want Brazil to become EU's dump!" CSOs also sent letters to Brazilian representatives, alluding to the fact that, by exporting used tires, EU would de facto reduce the burden of disposal in its own territory and transfer it to other countries ( $O$ caso dos pneus na OMC 2006). Between $5^{\text {th }}$ and $7^{\text {th }}$ of July, 2006, CSOs also protested in front of the WTO headquarters in Geneva. The mobilization of Brazilian CSOs was boosted by the participation of transnational actors such as the Institute for Agriculture and Trade Policy (IATP). In 2006, the Brazilian producers in the segment of importing used tires for retreading, represented by Associação Brasileira do Segmento de Reforma de Pneus (ABR), attested that the "media had been overcrowded with news stories against retreading companies" (Moura 2006, 1). That seems to indicate that indeed CSOs were strongly mobilized to 'make noise' to convince the Brazilian Congress to take their side.

ABR did not stand still, however. The association was largely against any import prohibition and followed closely the evolution of the WTO dispute involving retreaded tires, even threatening to resort to judicial channels to question certain decisions taken by the Brazilian Ministry of Foreign Affairs (Logweb 2007). As a result, it was difficult to convince members of the Executive concerned about economic repercussions of potential import prohibitions (Varella 2014) to take a stance that would grant a full victory to CSOs. As the interests at play mobilized, the veto possibilities of Brazil's policy process weighed in. Brazil has a "surplus" of veto players in its executive-legislative relations, something which is intrinsically associated with Brazil's coalitional presidentialism, in which each governing party is a potential veto player (Power 2010). This reflects in the Executive, as relevant ministries are appointed to reflect party coalitions formed to overcome the constraints of minority presidentialism. Therefore, it is possible to consider that strong preferences and strong veto possibilities reinforced each other and led to the inability of all sides in the dispute to achieve a substantive victory without facing the prospect of a veto (coming either from Congress or from Ministries). That, in turn, may have led to the long gestation of a compromise.

The fact that mobilization and veto players are plausibly shown to have mattered in the Brazil-tires controversy lends more confidence to the argument that countries with lower relative power will not necessarily be at the mercy of powerful trade actors. Similar findings have been

\footnotetext{
${ }^{7}$ Portaria SECEX 8/2000, Portaria SECEX 14/2004, Portaria DECEX 8/1991, Resolution CONAMA 23/1996, Presidential Decree 3.919 and Law 12.114 of the State of Rio Grande do Sul.
} 
underscored by the Brazilian scholarship in the case of the pharmaceutical patent controversy involving Brazil and the US (Oliveira and Moreno 2007). Instead, whenever domestic interests with diverging preferences are mobilized, domestic imperatives may trump international pressure (EC wanted the dispute to be over quickly so that its exporters could once more sell to Brazil without the risk of facing import barriers). Brazil ended up de jure losing the dispute, something which also underscores how difficult it is for a case to pass the two-tiered test presented by GATT Article XX. Still, the dispute was seen as a "multilateral victory" in the eyes of Brazilian diplomats (Marega 2013), as the WTO judges recognized the motives that led Brazil to impose restrictions on the importation of used and retreaded tires. All in all, the case illustrates that while the QCA method employed in this paper can offer a broad picture of the target category ("exceptional" disputes), its results are also plausible at the within-case level.

\section{Conclusion}

This paper delved into the combinations of conditions that explain the length of WTO disputes that invoke GATT's General Exceptions (Article XX). The study of "exceptional" disputes allows the understanding of a category of controversies that differ from the average WTO dispute in what it is composed of policies deemed special enough to circumvent GATT's rules. In turn, this paper studied dispute length using a set-theoretical approach which allowed it to overcome some of the main limitations of the existing large-n and small-n literature on WTO compliance. My findings indicate that certain predictions applicable to general disputes also hold for "exceptional" cases. In particular, the role of mobilization and bargaining power is to be highlighted. Still, mobilization and bargaining asymmetries do not operate independently. For the target category as a whole, domestic and international conditions only matter in conjunction. In addition, none of the conditions studied are necessary or sufficient in their own. Controversies invoking GATT Article XX are marked by a large degree of causal complexity: domestic and/or international conditions can matter in different ways to the outcome (dispute length).

This research reinforces the potential impact of the mobilization of civil society organizations in WTO compliance. The Brazil-EC dispute over retreaded tires offers an interesting example of that, therefore nuancing the perception that civil society organizations have no or very little influence when it comes to compliance with WTO's rulings. In terms of implications to state-to-state dispute settlement, this article suggests that governments' compliance responses in "exceptional" disputes cannot afford insulating CSOs. At the same time, however, the findings indicate that there are no "silver bullets" to understand compliance in "exceptional" disputes. In other words, the presumption of exceptionality of disputes invoking GATT Art. XX does not mean that there is one clear causal pathway to explain those disputes. That, in turn, underscores the importance of having in-depth case studies in parallel to medium and large-n studies on the political determinants of those controversies. 
It is important to underscore that the coverage of the cases is not particularly high in the main and in the alternative model, therefore results should always be approached with care, also in view of the limitations associated with calibration thresholds.

This work is to a large extent exploratory. Future research could profit from an in-depth study of the cases invoking GATT Article XX, having in mind the solutions displayed in the truth table of this article. Those studies can help indicate if there are specific within-case variations in the conditions analyzed (i.e., veto players) that could influence the analysis of WTO compliance response. Because QCA is still a method largely unknown - and therefore underused - by the Brazilian IR scholarship, there is a lot of space for its application in the Brazilian and South American context. Even internationally, it has only recently started being applied to IR and IPE analyses of WTO disputes. Having in mind its great potential, another avenue for research at the national and regional level is to use QCA to analyze disputes in which Brazil and other Mercosur/ South American/Latin American countries act as respondents or complainants. Those works could rely on conditions such as regional membership and trade agreements in negotiation, for instance, to shed new light on the determinants of WTO compliance responses in the region.

\section{Acknowledgements}

The author would like to thank the participants of the EUI-IHEID-Oxford Graduate Workshop (Florence, 2019) for the comments on an earlier version of the manuscript.

\section{References}

Beyers, J., A. Dür, and A. Wonka. “The political salience of EU policies.” Journal of European Public Policy 25, no. 11 (2015): 1726-37 doi: https://doi.org/10.1080/135017 63.2017 .1337213

Binder, S., and E. Neumayer. "Environmental pressure group strength and air pollution: an empirical analysis." Ecological Economics 55, no. 4 (2005): 527-38. doi: https://doi. org/10.1016/j.ecolecon.2004.12.009

Bohlmet, T., T. Bernauer, and V. Volbi. "The marginal impact of ENGOs in different types of democratic systems." European Political Science Review 7, no. 1 (2015): 93-118. doi: https://doi.org/10.1017/S175577391400006X

Bohmelt, T., and G. Spilker. The WTO dispute settlement mechanism: enforcement, state power and dispute recurrent. Bern: NCCR Trade Regulation, 2013. Working Paper, no. 71.

Brimeyer, B. "Banana, beef, and compliance in the World Trade Organization: the inability of the WTO dispute settlement process to achieve compliance from superpower nations." Minnesota Journal of Global Trade 10, no. 1 (2001): 133-68. 
Cezar, R. F. “The politics of 'dolphin-safe' tuna in the United States: policy change and reversal, lock-in and adjustment to international constraints (1984-2017).” World Trade Review 17, no. 4 (2018): 635-63. doi: https://doi.org/10.1017/S1474745617000416

Cezar, R. F. "Food certification, domestic politics and international trade: the US compliance response in three WTO disputes." Environmental Politics, (2019), doi: https://doi.org/10.1080/09644016.2019.1565462

Dür, A., P. Bernhagen, and D. Marshall. "Interest group success in the european union: when (and why) does business lose?” Comparative Political Studies 48, n. 8 (2015): 951-83. doi: https://doi.org/10.1177/0010414014565890

Dür, A. and D. De Bièvre. "Inclusion without Influence? NGOs in European Trade Policy.” Journal of Public Policy 27, no.1 (2007): 79-101. doi: https://doi.org/10.1017/ S0143814X0700061X

Dür, A. and G. Mateo. "Public opinion and interest group influence: how citizen groups derailed the anti-counterfeiting trade agreement." Journal of European Public Policy 21, no. 8, (2014): 1199-217. doi: https://doi.org/10.1080/13501763.2014.900893

Epple, R., M. Gasser, S. Kersten, M. Nollert, and S. Schief. "Institutions and gender time inequality: a fuzzy-set QCA of Swiss cantons." Swiss Journal of Sociology 40, no. 2 (2014): 259-78.

Garner, B. Black's law dictionary, St. Paul, MN: West Group, 1999.

Johnson, E., and A. Prakash. "NGO research program: a collective action perspective." Policy Science 40, no. 3 (2007): 221-40. doi: https://doi.org/10.1007/s11077-0079043-x

Keck, M. E., and K. Sikkink. Activists beyond borders: advocacy networks in international politics. Ithaca, NY: Cornell University Press, 1998.

Marega, F. "O contencioso sobre pneus reformados na OMC: uma importante vitória multilateral do Brasil." In O sistema de solucao de controversias da OMC, organized by D. Benjamin, 155-84. Brasilia, DF: FUNAG, 2013.

Mavroidis, P. On compliance in the WTO: enforcement among unequal disputants. Geneva: CUTS, 2012. Briefing Paper no. 4.

Moura, H. C. "Não somos importadores de lixo!” Revista PNEWS, October 2006. http:// www.abr.org.br/Palavra\%20Pres/palavra_10.html.

O caso dos pneus na OMC. São Paulo, SP: Fórum Brasileiro de ONGs e Movimentos Sociais para o Meio Ambiente e Desenvolvimento, 2006. https://fboms.org.br/campanhas/ocaso-dos-pneus-na-omc/

Oliveira, M. F., and F. V. Moreno. "Negociaçóes comerciais internacionais e democracia: o contencioso Brasil x EUA das patentes farmacêuticas na OMC.” Dados 50, n. 1 (2007): 189-220. doi: https://doi.org/10.1590/S0011-52582007000100007

Olson, M. The logic of collective action: public goods and the theory of groups. Cambridge: Harvard University Press, 1977. 
Poletti, A., and D. De Bièvre. "Political mobilization, veto players, and WTO litigation: explaining European Union responses in trade disputes.” Journal of European Public Policy 21, no. 8 (2014), 1181-98. doi: https://doi.org/10.1080/13501763.2014.897208

Power, T. J. "Optimism, pessimism, and coalitional presidentialism: debating the institutional design of brazilian democracy." Bulletin of Latin American Research 29, no. 1 (2010): 18-33.

Ragin, C. "Set relations in social research: evaluating their consistency and coverage." Political Analysis 14, no. 3 (2006): 291-310. doi: https://doi.org/10.1093/pan/mpj019

Rasmussen, A., B. Carroll, and D. Lowery. "Representatives of the public? Public opinion and interest groups activity." European Journal of Political Research 53, no. 2 (2014): 250-68. doi: https://doi.org/10.1111/1475-6765.12036

Sattler, T., and T. Bernauer. "Gravitation or discrimination? Determinants of litigation in the World Trade Organization.” European Journal of Political Research 50, no. 2 (2015): 143-67. doi: https://doi.org/10.1111/j.1475-6765.2010.01924.x

Sattler, T., G. Spilker, and T. Bernauer. "Does WTO dispute settlement enforce or inform?" British Journal of Political Science 44, no. 4 (2014): 877-902. doi: https://doi. org/10.1017/S0007123413000136

Schneider, C., and S. Maerz. "Legitimation, cooptation, repression and the survival of electoral autocracies." Zeitschrift für Vergleichende Politikwissenschaft 11, no. 1 (2017): 213-25. doi: https://doi.org/10.1007/s12286-017-0332-2

Wagemann, C., and C. Schneider. Standards of good practice in qualitative comparative analysis (QCA) and fuzzy-sets. Working paper, 2007. http://www.compasss.org/wpseries/ WagemannSchneider2007.pdf

Schelling, T. The strategy of conflict. Cambridge, MA: Harvard University Press, 1980. Spilker, G. Compliance with WTO rulings. Working paper no 2011/25, July 2012.

Thomman, E., I. -E. Oana, and S. Wittwer. Performing fuzzy-and crisp set QCA with R: beginner's guide. Working paper, 2018. http://www.evathomann.com/links/qca-r-manual. Tsebelis, G. "Decision making in political systems: veto players in presidentialism, parliamentarism, multicameralism and multipartyism." British Journal of Political Science 25, no. 3 (1995): 289-325. doi: https://doi.org/10.1017/S0007123400007225

Tsebelis, G. Veto players: how political institutions work. Princeton, NJ: Princeton University Press, 2012.

Varella, M. D. "Dificuldades de implementação das decisões da OMC: um estudo de caso a partir do contencioso pneus." Revista Direito GV 10, no. 1 (2014): 53-68. doi: https:// doi.org/10.1590/S1808-24322014000100003.

Working with civil society in foreign aid: possibilities for south-south cooperation? Beijing: United Nations Development Programme, 2013.

WTO dispute settlements: one-page case summaries. Geneva: World Trade Organizations, 2017. https://www.wto.org/english/res_e/booksp_e/dispu_settl_1995_2017_e.pdf 
Yildirim, A. "Domestic political implications of global value chains: explaining EU responses to litigation at the World Trade Organization." Comparative European Politics 16, no. 4 (2018): 549-80. doi: https://doi.org/10.1057/S41295-016-0085-3

Young, A. "Where's the demand? Explaining the EU's surprisingly constructive response to adverse WTO rulings." Journal of European Integration 41, no. 1 (2019). doi: https://doi. org/10.1080/07036337.2018.1544250 